\title{
CHROMIUM IN SOIL ORGANIC MATTER AND COWPEA AFTER FOUR CONSECUTIVE ANNUAL APPLICATIONS OF COMPOSTED TANNERY SLUDGE
}

\author{
Mara Lucia Jacinto Oliveira(1), Ademir Sérgio Ferreira de Araujo(1)* and Wanderley \\ José de Melo(2)
}

(1) Universidade Federal do Piauí, Centro de Ciências Agrárias, Departamento de Engenharia Agrícola e Solos, Campus da Socopo, Teresina, Piaui, Brasil.

(2) Universidade Estadual Paulista Júlio de Mesquita Filho, Faculdade de Ciências Agrárias e Veterinárias de Jaboticabal, Departamento de Tecnologia, Jaboticabal, São Paulo, Brasil.

* Corresponding author.

E-mail: ademir@ufpi.edu.br

\begin{abstract}
Tannery sludge contains high concentrations of inorganic elements, such as chromium (Cr), which may lead to environmental pollution and affect human health The behavior of $\mathrm{Cr}$ in organic matter fractions and in the growth of cowpea (Vigna unguiculata L.) was studied in a sandy soil after four consecutive annual applications of composted tannery sludge (CTS). Over a four-year period, CTS was applied on permanent plots $(2 \times 5 \mathrm{~m})$ and incorporated in the soil $(0-20 \mathrm{~cm})$ at the rates of $0,2.5,5.0,10.0$, and $20.0 \mathrm{Mg} \mathrm{ha}^{-1}$ (dry weight basis). These treatments were replicated four times in a randomized block design. In the fourth year, cowpea was planted and grown for 50 days, at which time we analyzed the $\mathrm{Cr}$ concentrations in the soil, in the fulvic acid, humic acid, and humin fractions, and in the leaves, pods, and grains of cowpea. Composted tannery sludge led to an increase in $\mathrm{Cr}$ concentration in the soil. Among the humic substances, the highest $\mathrm{Cr}$ concentration was found in humin. The application rates of CTS significantly increased $\mathrm{Cr}$ concentration in leaves and grains.
\end{abstract}

Keywords: soil contamination, humic substances, solid residue, heavy metals, plant growth, trace elements. 


\title{
RESUMO: CROMIO NA MATÉRIA ORGÂNICA DO SOLO E FEIJÃO-CAUPI, APÓS QUATRO APLICAÇÕES ANUAIS CONSECUTIVAS DE LODO DE CURTUME COMPOSTADO
}

\begin{abstract}
O lodo de curtume compostado contém elevadas concentrações de elementos inorgânicos, como o crômio $(\mathrm{Cr})$, que podem levar à poluição ambiental e influenciar na saúde humana. O comportamento envolvendo o Cr nas frações da matéria orgânica e no crescimento do feijão-caupi (Vigna unguiculata L.) foi estudado em solo arenoso, após quatro anos de aplicações anuais consecutivas de lodo de curtume compostado (LCC). Durante quatro anos, o LCC foi aplicado em parcelas permanentes $(2 \times 5 \mathrm{~m})$ e incorporado no solo (0-20 cm), nas doses de 0; 2,5; 5,0; 10,0 e 20,0 $\mathrm{Mg} \mathrm{ha}^{-1}$ (base seca). Esses tratamentos foram repetidos quatro vezes em blocos ao acaso. No quarto ano, o feijão-caupi foi semeado e cresceu por 50 dias, quando se analisaram as concentrações de Cr no solo, nas frações ácidos fúlvicos, ácidos húmicos e humina, nas folhas, nas vagens e nos grãos do feijão-caupi. O LCC promoveu aumento na concentração de Cr no solo. Entre as substâncias húmicas, a maior concentração de Cr foi encontrada na humina. As doses de LCC elevaram o teor de Cr nas folhas e grãos.
\end{abstract}

Palavras-chave: contaminação do solo, substancias húmicas, resíduo sólido, metais pesados, crescimento vegetal, elementos-traço.

\section{INTRODUCTION}

The tannery industry represents an important activity in the Brazilian economy, processing 44 million units of leather annually and, consequently, generating a high quantity of tannery sludge (Santos et al., 2011). Tannery sludge contains high concentrations of inorganic elements, such as chromium (Cr), which may lead to environmental pollution and affect human health (Gupta and Sinha, 2007). However, such waste also contains organic matter and plant nutrients that can improve soil fertility and plant growth (Hargreaves et al., 2008; Santos et al., 2011). Composting tannery sludge may be useful for stabilizing nutrients presents in sludge (Castaldi et al., 2004) and decreasing sludge toxicity (Araújo and Monteiro, 2005). Some studies have already been conducted using composted tannery sludge in different crops, such as soybean and maize (Ferreira et al., 2003) and cowpea (Teixeira et al., 2006; Silva et al., 2013). These studies showed an increase in plant yield after amending the soil with composted tannery sludge. However, there were increases in $\mathrm{Cr}$ concentration in soils and plants treated with this residue.

The behavior of $\mathrm{Cr}$ in soils treated with tannery sludge is influenced by its valence state of $\mathrm{Cr}^{3+}$ being stable in soil (Milacic and Stupar, 1995; McBride, 2002). Usually, neutral or alkaline soils exhibit $\mathrm{Cr}$ in the trivalent form $\left(\mathrm{Cr}^{3+}\right)$, which has low solubility and mobility (Alcântara and Camargo, 2001). In addition, $\mathrm{Cr}$ availability to plants is influenced by soil organic matter and its different fractions (Milacic and Stupar, 1995). According to Branzini and Zubillaga (2012), organic matter is effective in immobilization of $\mathrm{Cr}$ in soil. We hypothesized that soil with more humified organic matter would have lower $\mathrm{Cr}$ bioavailability, reducing the accumulation of this metal in plants.

The aim of this study was to evaluate $\mathrm{Cr}$ concentration in the soil, in the organic matter fractions, and in cowpea plants after four consecutive years of application of rates of composted tannery sludge to the soil.

\section{MATERIAL AND METHODS}

The experimental site is located at the Agricultural Science Center, Teresina, Piaui, Brazil $\left(05^{\circ} 05^{\prime} \mathrm{S} ; 42^{\circ} 48^{\prime} \mathrm{W}, 75 \mathrm{~m}\right)$. Climate in the region is dry tropical (Köppen), and it is characterized by two distinct seasons, a rainy summer and dry winter, with annual average temperatures of $30^{\circ} \mathrm{C}$ and annual rainfall of $1,200 \mathrm{~mm}$. The rainy season extends from January to April when $90 \%$ of total annual rainfall occurs.

Each year, composted tannery sludge (CTS) was produced by mixing tannery sludge with sugarcane bagasse and cattle manure (1:3:1; v:v:v). The composting process was carried out using the aerated-pile method for 85 days. Pile dimensions were $2 \times 1 \times 1.5 \mathrm{~m}(\mathrm{l} \times \mathrm{w} \times \mathrm{h})$. The pile was turned over twice a week for the first 30 days. After that, it was turned over twice a month for an additional 55 days. At the end of the composting process, 20 subsamples were randomly collected from the CTS to produce a composite sample. The N, P, and $\mathrm{K}$ contents were evaluated in this sample using Kjeldahl, colorimetry, and photometry methods, respectively. The other elements and trace elements $(\mathrm{Cr}, \mathrm{Cd}, \mathrm{Ni}$, and $\mathrm{Pb}$ ) were evaluated by atomic absorption spectrophotometry according to 
the 3050B method (USEPA, 1996), which consists of solubilization of the sample with $\mathrm{HNO}_{3}, \mathrm{HCl}$, and $\mathrm{H}_{2} \mathrm{O}_{2}$ concentrated under heating and absorbance reading using air-acetylene-nitrous oxide-acetylene flame (Cr) or air-acetylene flame.

For four years (2009-2012), CTS was applied on the permanent plots $(2 \times 5 \mathrm{~m})$ and incorporated into the soil $(0-20 \mathrm{~cm})$ at the rates of $0,2.5,5.0,10.0$, and $20.0 \mathrm{Mg}^{-1} \mathrm{H}^{-1}$ (dry weight basis). Phosphorus and K were added as necessary based on soil analysis in order to provide all the plots with the same $\mathrm{P}$ and $\mathrm{K}$ level. The $\mathrm{P}$ and $\mathrm{K}$ levels in the plots were within the range required by cowpea (Freire Filho et al., 2012). A completely randomized experimental design was used, with four replicates. Plots were marked out $\left(20 \mathrm{~m}^{2}\right.$ each, with $12 \mathrm{~m}^{2}$ useful area for soil and plant sampling), with rows spacing of $1.0 \mathrm{~m}$.

In the fourth year (2012), CTS was applied ten days before sowing cowpea (Vigna unguiculata). It was spread on the soil surface and incorporated in the $20 \mathrm{~cm}$ layer with a harrow. Cowpea was grown at a rate of five plants $\mathrm{m}^{-1}$ (about 62,000 plants ha-1). Data were collected 60 days after CTS application. The shoots, pods and grains of cowpea were sampled from 10 plants in each plot.

Four soil samples were collected from each plot $(0-20 \mathrm{~cm})$ and pooled to form a composite sample per plot. Soil organic matter fractionation in fulvic acids, humic acids, and humin was performed according to the method proposed by the International Humic Substances Society (IHSS), as described in Swift (1996). A $0.1 \mathrm{~mol} \mathrm{~L}^{-1} \mathrm{NaOH}$ solution was used for extraction from the soil samples until exhaustion of organic matter. This extract (humic substances) was acidified to $\mathrm{pH} 1.0$ with concentrated $\mathrm{H}_{2} \mathrm{SO}_{4}$, and the precipitate (humic acids) was suspended in $0.1 \mathrm{~mol} \mathrm{~L}^{-1}$ $\mathrm{NaOH}$ solution. Chromium concentration in plant, soil, and organic matter fractions were analyzed using acid digestion with $\mathrm{HNO}_{3}, \mathrm{HCl}$, and $\mathrm{H}_{2} \mathrm{Cl}_{2}$ concentrated under heating and absorbance reading was made in AAS using nitrous oxide-acetylene flame (USEPA, 1996). Validation of the method was carried out with certified reference material, as shown in table 1. It is important to note that the USEPA (1996) method does not estimate all the trace elements present in the soil.

Analysis of variance was used for statistical analysis and the mean values were compared by Student's $t$ test at $5 \%$ significance. Regression analysis was not carried out because the mineral fertilizers used may also contain trace elements.

\section{RESULTS AND DISCUSSION}

Recovery of $\mathrm{Cr}$ contained in the reference analytical materials [Tomato leaves - NIST SRM $1573 \mathrm{a}$, and soil contaminated with sewage sludge - RTC CRM 005-050 (USEPA, 2007)] was 92.45\% for plants and $57.09 \%$ for soil. It is well known that the 3050B method (USEPA, 1996) is not able to totally solubilize soil, sediment, and sludge samples, so this procedure is recommended for studies on environmental contamination and pollution since it evaluates the maximal trace elements potentially available to plants (Andrade et al., 2014). The selection of this method was based on the objective of estimating the environmental availability of trace elements. Thus, recovery of the $\mathrm{Cr}$ in the reference samples may be considered satisfactory when compared to the methods using $\mathrm{HNO}_{3}, \mathrm{HCl}, \mathrm{H}_{2} \mathrm{O}_{2}$, and HF (Chen and Ma, 2001; Vieira et al., 2005).

Composted tannery sludge (CTS) exhibited high $\mathrm{pH}$ values, organic $\mathrm{C}$, and $\mathrm{Cr}$ content (Table 2 ). Consequently, after four years, application of CTS significantly increased soil $\mathrm{pH}$, soil organic matter (SOM), and $\mathrm{Cr}$ content (Table 3). Soil pH increased

Table 1. Recovery of trace elements by the methods used in the analysis of the certified material

\begin{tabular}{|c|c|c|c|c|}
\hline Element & Certified material(1) & \multicolumn{2}{|c|}{ Certified value } & Recovery \\
\hline & & \multicolumn{2}{|c|}{$\mathrm{mg} \mathrm{kg-1}$} & $\%$ \\
\hline \multirow[t]{2}{*}{$\mathrm{Cd}$} & NIST SRM 1573a & 1.52 & 1.87 & 123.0 \\
\hline & RTC CRM 005-050 & 13.70 & 13.76 & 100.4 \\
\hline \multirow[t]{2}{*}{$\mathrm{Cr}$} & NIST SRM $1573 a$ & 1.99 & 1.04 & 55.3 \\
\hline & RTC CRM 005-050 & 41.30 & 48.06 & 117.2 \\
\hline \multirow[t]{2}{*}{$\mathrm{Cu}$} & NIST SRM 1573a & 4.70 & 4.46 & 94.9 \\
\hline & RTC CRM 005-050 & 465.40 & 387.75 & 83.3 \\
\hline \multirow[t]{2}{*}{$\mathrm{Ni}$} & NIST SRM 1573a & 1.59 & 0.42 & 26.4 \\
\hline & RTC CRM 005-050 & 26.00 & 29.95 & 115.2 \\
\hline \multirow[t]{2}{*}{$\mathrm{Zn}$} & NIST SRM $1573 a$ & 30.90 & 29.43 & 95.2 \\
\hline & RTC CRM 005-050 & 625.20 & 619.25 & 99.0 \\
\hline
\end{tabular}

(1) Tomato leaves - NIST SRM 1573a and soil contaminated with sewage sludge - RTC CRM 005-050. 
above 7.0 due to CTS rates and, at alkaline $\mathrm{pH}$ values, heavy metals remain inert in the soil under forms with low mobility (Hayes and Traina, 1998). At $\mathrm{pH}$ values above 5.0, especially $\mathrm{Cr}$ is in an insoluble form $\left[\mathrm{Cr}(\mathrm{OH})_{3}\right]$ (Aquino Neto and Camargo, 2000), reducing its toxic potential. Although $\mathrm{Cr}$ concentration increased in the soil, the values found are below the limit for agricultural soils (75 mg kg-1) according to Conama (2009). Even at the highest CTS rate, Cr concentration was half the limit for soil. However, from the first to the fourth year, $\mathrm{Cr}$ concentration in the soil showed more than a fivefold increase.

Table 2. Chemical properties of composted tannery sludge (CTS) and the limits permitted for heavy metal (Limit) by National Environment Council (Conama)

\begin{tabular}{|c|c|c|c|c|}
\hline \multirow[t]{2}{*}{ Property } & \multicolumn{3}{|c|}{ Composted tannery sludge } & \multirow[t]{2}{*}{ Limit(1) } \\
\hline & 2009 & 2010 & 2011 & \\
\hline $\mathrm{pH}$ & 7.8 & 7.2 & 7.5 & \\
\hline $\mathrm{C}\left(\mathrm{g} \mathrm{kg}^{-1}\right)$ & 187.5 & 195.3 & 201.2 & \\
\hline $\mathrm{N}\left(\mathrm{g} \mathrm{kg}^{-1}\right)$ & 1.28 & 1.39 & 1.51 & \\
\hline $\mathrm{P}\left(\mathrm{g} \mathrm{kg}^{-1}\right)$ & 4.02 & 3.83 & 4.91 & \\
\hline $\mathrm{K}\left(\mathrm{g} \mathrm{kg}^{-1}\right)$ & 3.25 & 3.51 & 2.90 & \\
\hline $\mathrm{Ca}\left(\mathrm{g} \mathrm{kg}^{-1}\right)$ & 95.33 & 84.28 & 121.18 & \\
\hline $\operatorname{Mg}\left(\mathrm{g} \mathrm{kg}^{-1}\right)$ & 6.80 & 5.71 & 7.21 & \\
\hline $\mathrm{S}\left(\mathrm{g} \mathrm{kg}^{-1}\right)$ & 9.39 & 8.43 & 10.20 & \\
\hline $\mathrm{Cu}\left(\mathrm{mg} \mathrm{kg}{ }^{-1}\right)$ & 17.80 & 19.51 & 16.38 & 1500 \\
\hline $\mathrm{Zn}\left(\mathrm{mg} \mathrm{kg} \mathrm{k}^{-1}\right)$ & 141.67 & 128.31 & 127.81 & 2800 \\
\hline $\mathrm{Ni}(\mathrm{mg} \mathrm{kg}-1)$ & 21.92 & 28.61 & 23.26 & 420 \\
\hline $\mathrm{Cd}\left(\mathrm{mg} \mathrm{kg}^{-1}\right)$ & 2.87 & 3.93 & 1.93 & 39 \\
\hline $\mathrm{Cr}(\mathrm{mg} \mathrm{kg}-1)$ & 2.26 & 2.58 & 1.94 & 1000 \\
\hline $\mathrm{Pb}(\mathrm{mg} \mathrm{kg}-1)$ & 42.67 & 38.54 & 40.31 & 300 \\
\hline
\end{tabular}

(1) According to Conama (2009).
Results for $\mathrm{Cr}$ concentration in the organic matter fractions showed that more than $57 \%$ of the metal present in the soil was bound to humic substances, and the highest concentration was found in the humin (Table 3).

Humic substances contain a large number of complexing sites; hence they behave as a natural "multiligand" complexing system (Buffle, 1988). The high degree of selectivity of SOM for most trace elements in cationic form indicates that they form inner-sphere complexes with the functional groups, often forming an internal five- or sixmember ring on structures (Huang and Germida, 2002; Sparks, 2003). The high Cr bond with humin occurred because this fraction is more stable and strong for complex mineral elements. The $\mathrm{Cr}$ concentrations in the humic and fulvic acids were very similar (Table 3). Unlike $\mathrm{Cr}$ bound to humin, $\mathrm{Cr}$ bound to humic and fulvic acids is more available to plants and to percolation through the soil profile. Composted tannery sludge increased $\mathrm{Cr}$ concentration in the organic fractions, fulvic acids, humic acids, and humin, compared to the control. $\mathrm{Cr}$ concentration in the fulvic acid and humin fractions increased with the increase in the rate of compost application, but this was not observed for the humic acid fraction. This result was probably due to the time between compost applications and sampling, which was enough for transformation of the humic acids to humin, but not for polymerization of fulvic acids to humic acids; or the velocity of the transformation of humic acids to humin was higher than the transformation of fulvic acids to humic acids. Finally, it is possible that the transformation of the composted organic matter to fulvic acids was higher than the transformation of fulvic acids to humic acids and, consequently, to humin.

Chromium concentration significantly increased in leaves and grains after CTS application (Table 3). There was not a significant difference in $\mathrm{Cr}$ concentration in the pods. The increase in $\mathrm{Cr}$ concentration in the leaves may be related to higher soil $\mathrm{Cr}$ concentration after CTS application and, therefore, the metal was translocated from the roots to the leaves. This difference in $\mathrm{Cr}$ accumulation in

Table 3. pH values, soil organic matter (SOM), and $\mathrm{Cr}$ in the soil, fulvic acids (Cr-FA), humic acids (Cr-HA), and humin (Cr-HUM) fractions and chromium concentration in leaves, pods, and grains of cowpea after four years of composted tannery sludge (CTS) application

\begin{tabular}{|c|c|c|c|c|c|c|c|c|c|}
\hline CTS & pH & SOM & Cr-soil & Cr-FA & Cr-HA & C-HUM & Cr-leaf & Cr-pod & Cr-grain \\
\hline $\mathrm{Mg} \mathrm{ha}^{-1}$ & & $\mathrm{~g} \mathrm{~kg}^{-1}$ & & & & $\mathrm{mg} \mathrm{kg}^{-1}$ & & & \\
\hline 0 & $6.6 \mathrm{~b}$ & $17.88 \mathrm{c}$ & $6.73 \mathrm{e}$ & $0.63 \mathrm{c}$ & $0.71 \mathrm{~b}$ & $2.5 \mathrm{~d}$ & $1.56 \mathrm{~d}$ & $1.24 \mathrm{a}$ & $0.55 \mathrm{c}$ \\
\hline 2.5 & $6.9 \mathrm{~b}$ & $19.12 \mathrm{c}$ & $12.7 \mathrm{~d}$ & $0.85 \mathrm{c}$ & $2.12 \mathrm{a}$ & $7.9 \mathrm{c}$ & $3.00 \mathrm{c}$ & $1.04 \mathrm{a}$ & $0.99 \mathrm{~b}$ \\
\hline 5.0 & $7.3 \mathrm{a}$ & $23.41 \mathrm{~b}$ & $26.8 \mathrm{c}$ & $1.32 \mathrm{~b}$ & $1.65 \mathrm{a}$ & $13.4 \mathrm{~b}$ & $5.41 \mathrm{~b}$ & $0.99 \mathrm{a}$ & $1.11 \mathrm{~b}$ \\
\hline 10.0 & $7.7 \mathrm{a}$ & $25.34 \mathrm{~b}$ & $30.4 \mathrm{~b}$ & $1.29 \mathrm{~b}$ & $1.96 \mathrm{a}$ & $18.2 \mathrm{a}$ & $7.80 \mathrm{a}$ & $1.15 \mathrm{a}$ & $1.62 \mathrm{a}$ \\
\hline 20.0 & $7.9 \mathrm{a}$ & $28.18 \mathrm{a}$ & $36.9 \mathrm{a}$ & $2.25 \mathrm{a}$ & $2.29 \mathrm{a}$ & $19.1 \mathrm{a}$ & $7.68 \mathrm{a}$ & $1.08 \mathrm{a}$ & $1.74 \mathrm{a}$ \\
\hline
\end{tabular}

Values followed by the same letter within each column are not significantly different at the $5 \%$ as determined by Student's $t$-test. 
the different parts of the plant suggests different cellular mechanisms of bioaccumulation of $\mathrm{Cr}$ and this may control $\mathrm{Cr}$ translocation and partitioning in the plant. Therefore, more $\mathrm{Cr}$ was accumulated in the leaves and grains than in the pods, and as $\mathrm{Cr}$ is a non-essential element, the plants may not possess any specific mechanism for transporting the Cr (Kumar and Chopra, 2012).

Although Cr concentration in the leaves increased, it did not exceed the limits proposed by Macnicol and Beckett (1985) for the bean crop (10 mg kg-1). However, $\mathrm{Cr}$ concentration in grain was above the limit ( $\left.0.1 \mathrm{mg} \mathrm{kg}^{-1}\right)$ for food and grains established by Anvisa (1965) and the limit mentioned by KabataPendias and Pendias (2001) (0.15 mg kg-1).

\section{CONCLUSIONS}

The application rates of composted tannery sludge applied to soils for four years led to an increase in the Cr levels in soil and fractions of the soil organic matter and tended to stabilize at the rates of 10.0 and $20.0 \mathrm{Mg} \mathrm{ha}^{-1}$.

The highest $\mathrm{Cr}$ concentration in the soil organic matter fractions is that bound to humin.

Soil $\mathrm{Cr}$ is available to be taken up by cowpea and it accumulates in leaves and grains.

\section{ACKNOWLEDGMENTS}

The authors are grateful to the CAPES for financial support and to the CNPq for the fellowships received (Research Productivity).

\section{REFERENCES}

Agência Nacional de Vigilância Sanitária - Anvisa. Decreto ${ }^{\circ}$ 55.871, de 26 de março de 1965. Brasília, DF: Ministério da Saúde; 1965 [cited 2013 Nov 20]. Available at: http://portal.anvisa.gov. $\mathrm{br} / \mathrm{wps} / \mathrm{wcm} /$ connect/414d248047458a 7d93f3d73fbc4c6735/ DECRETO+N\% $2 \% \mathrm{BA}+55.871 \% 2 \mathrm{C}+\mathrm{DE}+26+\mathrm{DE}+\mathrm{MAR} \% \mathrm{C} 3$ $\% 87 \mathrm{O}+\mathrm{DE}+1965$.pdf?MOD=AJPERES.

Alcântara MAK, Camargo OA. Movement of trivalent chromium as influenced by $\mathrm{pH}$, soil horizon and sources of chromium. R Bras Eng Agric Amb. 2001;5:497-501.

Andrade MG, Lima AST, Melo WJ, Santos EJ, Hermann AB. Elementos-traço em dois latossolos após aplicações anuais de lodo de esgoto por treze anos. Semina: Ci Agric. 2014;35:135-48.

Aquino Neto V, Camargo OA. Crescimento e acúmulo de crômio em alface cultivada em dois Latossolos tratados com $\mathrm{CrCl}_{3}$ e resíduos de curtume. R Bras Ci Solo. 2000;24:225-35.
Araújo ASF, Monteiro RTR. Plant bioassays to assess toxicity of textile sludge compost. Sci Agric. 2005;62:286-90.

Branzini A, Zubillaga MS. Comparative use of soil organic and inorganic amendments in heavy metals stabilization. Appl Environ Soil Sci. 2012; doi: 10.1155/2012/721032.

Buffle J. Complexation reactions in aquatic systems: An analytical approach. Chichester: Ellis Horwood; 1988.

Castaldi P, Garau G, Melis P. Influence of compost from sea weeds on heavy metal dynamics in the soil-plant system. Fresh Environ Bull. 2004;13:1322-8.

Chen M, Ma LQ. Comparison of three aqua regia digestion methods for twenty Florida soils. Soil Sci Soc Am J. 2001;65:491-9.

Conselho Nacional do Meio Ambiente - Conama. Resolução ${ }^{\circ}$ 420, de 28 de dezembro de 2009. Brasília, DF: Ministério do Meio Ambiente; 2009 [cited 2013 Jan 20]. Available at: http://www. $\mathrm{mma}$.gov.br/port/conama/legiano1.cfm? codlegitipo=3\&ano=2009.

Ferreira AS, Camargo FAO, Tedesco MJ, Bissani CA. Alterações de atributos químicos e biológicos de solo e rendimento de milho e soja pela utilização de resíduos de curtume e carbonífero. $\mathrm{R}$ Bras Ci Solo. 2003;27:755-63.

Freire Filho FR, Ribeiro VQ, Rocha MM, Silva KJD, Nogueira MSR, Rodrigues EV. Feijão-caupi no Brasil. Produção, Melhoramento Genético, Avanços e Desavanços. Ed. Teresina: Empresa Brasileira de Pesquisa Agropecuária; 2011.

Gupta AK, Sinha S. Phytoextraction capacity of the plants growing on tannery sludge dumping sites. Bioresour Technol. 2007;98:1788-94.

Hargreaves JC, Adl MS, Warman PRA. Review of the use of composted municipal solid waste in agriculture. Agric Ecosys Environ. 2008;123:1-14.

Hayes KF, Traina SJ. Metal ion speciation and its significance in ecosystem health. In: Huang PM, editor. Soil chemistry and ecosystems health. Madison: Soil Science Society of America; 1998. p.119-41.

Huang PM, Germida JJ. Chemical and biochemical processes in the rhizosphere: metal pollutants. In: Huang PM, Bollag JM, Senesi N, editors. Interaction between soil particles and microorganisms: Impact on the terrestrial ecosystem. New York: John Wiley \& Sons; 2002. p.381-438.

Kabata-Pendias A, Pendias H. Trace elements in soils and plants. $3^{\text {th }}$ ed. Boca Raton: CRC Press; 2001.

Kumar V, Chopra AK. Translocation of micronutrients in French bean (Phaseolus vulgaris L.) grown on soil amended with paper mill sludge. J Chem Pharma Res. 2012;4:4822-29.

Macnicol RD, Beckett PHT. Critical tissue concentrations of potentially toxic elements. Plant Soil. 1985;85:107-29.

McBride MB. Toxic metals in sewage sludge-amended soils: Has promotion of beneficial use discounted the risks? Adv Environ Res. 2002;167:62-7.

Milacic R, Stupar J. Fractionation and oxidation of chromium in tannery waste- and sewage sludge-amended soils. Environ Sci Technol. 1995;29:506-14.

Santos JA, Nunes LAPL, Melo WJ, Araújo ASF. Tannery sludge compost amendment rates on soil microbial biomass of two different soils. Eur J Soil Biol. 2011;47:146-51. 
Sparks DL. Environmental soil chemistry. 2nd ed. San Diego: Academic Press; 2003.

Silva MDM, Araújo ASF, Nunes LAPL, Melo WJ, Singh RP. Heavy metals in cowpea (Vigna unguiculata L.) after tannery sludge compost amendment. Chilean J Agric Res. 2013;73:282-7.

Swift RS. Organic matter characterization. In: Sparks D, editor. Methods of soil analysis: Chemical methods. Madison: Soil Science Society of America; 1996. Part 3, p.1018-20. (Series, 5).

Teixeira KRG, Gonçalves Filho LAR, Carvalho EMS, Araújo ASF, Santos VB. Efeito da adição de lodo de curtume na fertilidade do solo, nodulação e rendimento de matéria seca do caupi. $\mathrm{Ci}$ Agrotec. 2006;30:1071-6.
Vieira EC, Kamogawa MY, Lemos SG, Nóbrega JCA, Nóbrega RAA. Decomposição de amostras de solos assistida por radiação microondas: Estratégia para evitar a formação de fluoretos insolúveis. R Bras Ci Solo. 2005;29:547-53.

United States Environmental Protection Agency - Usepa. Method 3051A: microwave assisted acid digestion of sediments, sludges, soils, and oils. In: Sw-846: Test methods for evaluation solid waste physical and chemical methods. Washington, US: United States Environmental Protection Agency; 2007.

United States Environmental Protection Agency - Usepa. Method 3050B - Acid digestion of sediments, sludges and soils. Washington, US: United States Environmental Protection Agency; 1996 [cited 2012 April 02]. Available at: http://www.epa.gov/SW-846/pdfs/3050b.pdf. 